\title{
Effect of Mineral and Bio-N Fertilization on Growth, Fruits Yield and Chemical Constituents of Pumpkin (Cucurbita moschata Duchesne)
}

\author{
A.Sh. Osman and M. S. Tolba \\ Department of Horticulture, Faculty of Agriculture, Fayoum \\ University, Fayoum, Egypt.
}

\begin{abstract}
I IGNIFICANT positive influences of fertilization with $2 / 3$ of the recommended mineral- $\mathrm{N}$ dose + inoculation three times with a mixed bio-fertilizer (Azotobacter chroococcum + Azospirillium brasilense) were observed on growth traits, fruits yield and leaf $\mathrm{N}, \mathrm{P}$, $\mathrm{K}, \mathrm{NO}_{3}{ }^{-}$and $\mathrm{NO}_{2}^{-}$contents of pumpkin plants compared to fertilization with $2 / 3$ of the recommended mineral-N dos+ inoculation once or twice with the same mixed bio-fertilizer. However, no statistical differences in the aforementioned parameters were noted between fertilization with $2 / 3$ of the recommended mineral-N dose + inoculation three times with a mixed bio-fertilizer and addition of whole recommended dose of mineral-N (control). The least significant mean values of leaf $\mathrm{NO}_{3}{ }^{-}$ and $\mathrm{NO}_{2}^{-}$content were attained at fertilization with $2 / 3$ of the recommended mineral-N dose + inoculation three times with a mixed bio-fertilizer. Therefore, inoculation with a mixed bio-fertilizer three times can substitute partially of mineral-N fertilizer and contribute to safety food.
\end{abstract}

Keywords: Bio-fertilization, growth, nitrate, nitrite, yield, quality, pumpkin.

Pumpkin is widely cultivated on newly-reclaimed soils in the Middle Eastern countries, including Egypt. It is consumed in different local dishes and used for some food industries such as jams, purees and cakes. Mineral fertilizers, particularly mineral-nitrogen, are an important mean of plant nutrition, growth and yield; however, they are also a potential source of environmental pollution (Hartman, 1988). An attention has therefore focused on alternative fertilizers, including bio-fertilizers. Nowadays, there is renewed interest in bio-fertilizers for nutrient supply and improve soil fertility and productivity. The integrated use of bio-fertilizers and mineral fertilizers is considered the best option not only to reduce the intensive consumption of chemical fertilizers, but also to sustain the soil with minimum undesirable impacts and to maximize fertilizer use efficiency in soil (Singh et al., 1999, Bhatia et al., 2001 and Palm et al., 2001). Biofertilizers are considered eco-friendly way to sustainable agriculture. They positively affect plant growth and yield, reduce negative effects of chemical fertilizers and minimize some chemical levels such as $\mathrm{NO}_{3}{ }^{-}$and $\mathrm{NO}_{2}{ }^{-}$ions in the soil and consequently in plants. Therefore, the way to a healthy agriculture with a 
minimum pollution requires a conjunctive use of bio-nitrogen and mineralnitrogen fertilizers.

Bio-fertilizers, microbial inoculants that can promote plant growth and productivity, are internationally accepted as an alternative source of $\mathrm{N}$-fertilizer. In the bio-fertilizer technology, new systems are being developed to increase the biological $\mathrm{N}_{2}$-fixation with cereals and other non-legumes by establishing $\mathrm{N}_{2}$ fixing bacteria within the roots (Cocking, 2000). The mechanisms by which biofertilizers can exert a positive effect on plant growth can be through the synthesis of Phytohormones, reduction in membrane potential of roots, synthesis of some enzymes such as ACC deaminase that modulate the level of plant hormones. Free living $\mathrm{N}_{2}$-fixing bacteria such as Azotobacter and Azospirillum have the ability not only to fix nitrogen but also to release certain phytohormonsas gibberellins $\left(\mathrm{GA}_{3}\right)$, indole acetic acid (IAA) and cytokinins which could stimulate plant growth, increase the availability of nutrients for plant roots and increase the capacity of photosynthesis process (Ibrahim \& Abd El-Aziz, 1977, Fayez et al., 1985 and Abdel-Latif et al., 2001). Several reports indicated that the inoculation of some crops with bio-fertilizers singly or in combination with mineral fertilizers improved plant growth, yield and chemical composition (Hanafy et al., 1997, Gadallah \& El-Masry, 2006, Osman, 2007 and Howladar et al., 2013). Inoculation of potato tuber seeds with a mixed bio-fertilizer; Azotobacter chroococcum + Azospirillium brasilense significantly increased growth, tubers yield and its components (Ashour et al., 1997 and Osman, 2007).

The objective of the current study was to assess the effect of fertilization with mineral- $\mathrm{N}$ at the recommended dose versus application $2 / 3$ of the recommended mineral-N dose + inoculation with a mixed biofertilizer (Azotobacter chroococcum + Azospirillium brasilense) once, twice and thrice on growth traits, leaf chemical constituents specially nitrate and nitrite contents as contaminated agents, fruits yield and quality of pumpkin (Cucurbita moschata Duchesne) grown under Egyptian conditions.

\section{Material and Methods}

Two field experiments were conducted during the summer seasons of 2012 and 2013 at the experimental Farm, Faculty of Agriculture, Fayoum University, Egypt. In order to identify some physio-chemical properties of the experimental site, soil samples preceding the initiation of each experiment and 8 weeks after application of treatments were collected and analyzed according to the procedures of Wilde et al. (1985) and the obtained results are shown in Table 1.

Seeds of pumpkin cultivar balady were seeded in 11 and 20 March 2012 and 2013 , consecutively on rows $8 \mathrm{~m}$ long, $2 \mathrm{~m}$ wide and in-row spacing of $50 \mathrm{~cm}$. Each experiment included four treatments as follow:

Egypt. J. Hort. Vol. 41, No.1 (2014) 
- Fertilization with mineral $\mathrm{N}$ fertilizer at the recommended dose; $125 \mathrm{~kg} \mathrm{~N}$ $\mathrm{fed}^{-1}$ (control).

- Fertilization with $2 / 3$ of the recommended mineral $\mathrm{N}$ dose + inoculation once with a mixture of bio-N fertilizers (strains of Azotobacter chroococcum FN and Azospirillium brasilense FN 17 in a ratio of 1:1).

- Fertilization with $2 / 3$ of the recommended mineral $\mathrm{N}$ dose + inoculation twice with a mixture of bio-N fertilizers.

- Fertilization with $2 / 3$ of the recommended mineral $\mathrm{N}$ dose + inoculation thrice with a mixture of bio- $\mathrm{N}$ fertilizers.

The experimental layout was a randomized complete blocks design with four replicate. The area devoted for each experimental unit was $80 \mathrm{~m}^{2}$ including 5 rows. Each two adjacent experimental units were separated by $1 \mathrm{~m}$ alley. Mineral $\mathrm{N}$ fertilizer was applied during soil preparation and ammonium nitrate $(33.5 \% \mathrm{~N})$ was the respective form. Inoculation with mixed biofertilizer was performed after 2 weeks (once), 2 and 4 weeks (twice) and 2, 4 and 6 weeks (thrice) of seed sowing.

\section{Preparation of bio- $N$ fertilizer inoculant and inoculation}

Soil samples of the experimental site were collected and the strains of nonsymbiotic $\mathrm{N}_{2}$-fixing bacteria; A. chroococcum FN 33 and A. brasilense FN 17 were isolated and identified by the microbiology lab., Faculty of Agriculture, Fayoum University. Modified Ashby's medium (Hegazi and Niemela, 1976) and Dobereiner medium (Dobereiner et al., 1976) were used to grow A. chroococcum and A. brasilense, consecutively. At the logarithmic growth phase, cultures were centrifuged at $1000 \mathrm{rpm}$ and the cell pellets were washed three times with sterile phosphate buffer $(100 \mathrm{mM}, \mathrm{pH}=7.0)$. The washed cells were re-suspended in the same buffer to the final concentration of about $4 \times 10^{8} c f u \mathrm{ml}^{-1}$. Isolates and inoculates were prepared immediately before inoculation. The rhizosphere of each plant was injected with about $35 \pm 5 \mathrm{ml} \mathrm{plant}^{-1}$ of the aforementioned mixture of bio-fertilizers.

During soil preparation, identical doses of $15 \mathrm{~m}^{3}$ farmyard manure, $150 \mathrm{~kg}$ calcium superphosphate $\left(15.5 \% \mathrm{P}_{2} \mathrm{O}_{5}\right)$ and $100 \mathrm{~kg}$ elemental sulfur fed ${ }^{-1}$ were added while after complete earthing, $48 \mathrm{~kg} \mathrm{~K}_{2} \mathrm{O}$ fed $^{-1}$ at two equal portions; 20 and 40 days after seed sowing was applied. All other agro-management practices for commercial production of pumpkin were followed whenever it was necessary.

\section{Data recorded}

Growth measurements

After 8 weeks of seed sowing, five plants were randomly chosen from the outer two rows in each experimental unite, cut off at the ground level and the following measurements were recorded; plant height, number of leaves plant ${ }^{-1}$, canopy dry weight plant ${ }^{-1}$ after drying in a forced-air oven at $70{ }^{\circ} \mathrm{C}$ till constant weight and leaf area plant ${ }^{-1}$ using a digital LI-3000 Portable area meter (LI-COR Lincoln, Nebraska, USA). 


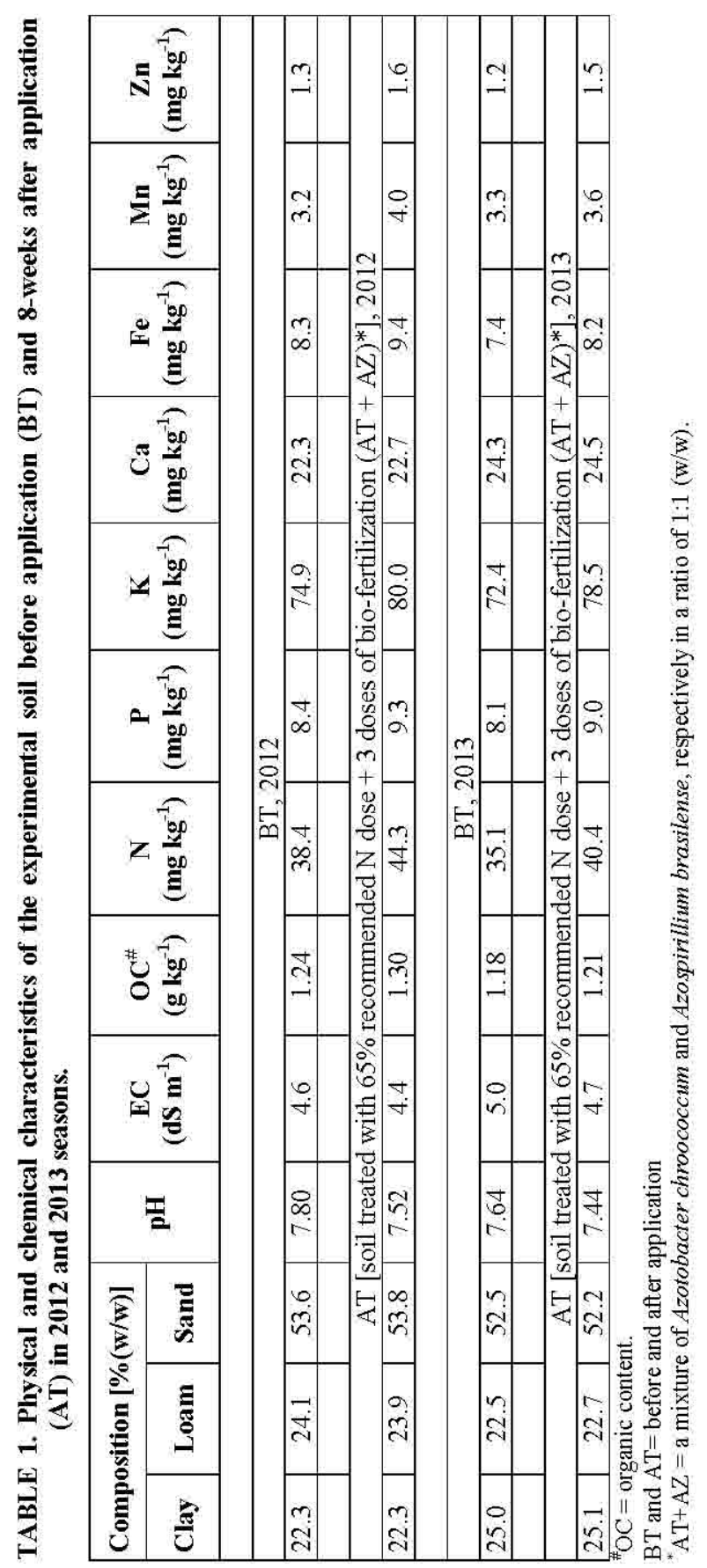

Egypt. J. Hort. Vol. 41, No.1 (2014) 


\section{Fruits yield and quality}

In each experimental unite, plants of the three inner rows were left to grow till fruits approached the marketable stage. Ten harvested fruits were utilized to measure the following parameters; average fruit weight $(\mathrm{kg})$, fruit length $(\mathrm{cm})$; longitudinal axe starting from peduncle to blossom end and maximum fruit diameter $(\mathrm{cm})$. Total fruits yield $\mathrm{fed}^{-1}$ (ton) was calculated from the entire harvested fruits of the three inner rows.

\section{Chemical constituents}

After 8 weeks of seed sowing, leaf $\mathrm{N}, \mathrm{P}$ and $\mathrm{K}$ contents were determined. Leaf $\mathrm{N}$ content was estimated using the Microkjeldahal apparatus as described in A.O.A.C. (1995). Leaf P content was determined as outlined by Jackson (1967). Leaf potassium content was assayed using a Perkin-Elmer Model 52-A Flame Photometer (Page et al., 1982).

Leaf samples for nitrate and nitrite determinations were collected 8 weeks after seed sowing. Leaf samples were washed with tap water, rinsed numerous times in distilled water, cut into small uniform size pieces and dried in a forcedair oven at $105 \mathrm{C}^{\mathrm{o}}$ until they became brittle and crisp to prevent contamination. The dried leaf samples were grounded and one gram of each sample was placed in a $100 \mathrm{ml}$ polyethylene or glass bottle and $40 \mathrm{ml}$ of distilled water was added, then capped and shacked for $30 \mathrm{~min}$. The solution sample was filtered and the filtrate was made up to $100 \mathrm{ml}$ in a volumetric flask (Radojevic and Bashkin, 1999). Spectrophotometer (Model 2000; Kwf Sci-Tech Development Co. Ltd., Beijing, P.R. China) at a wavelength of $543 \mathrm{~nm}$ was utilized to record leaf $\mathrm{No}_{3}-\mathrm{N}$ concentration. Leaf $\mathrm{NO}_{3}-\mathrm{N}$ concentration converted to $\mathrm{NO}_{3}{ }_{3}$ by multiplying in a conversion factor of 4.4( $\mathrm{La}$ Motte, 2000).Leaf $\mathrm{No}_{3}$ content was calculated according to the following formula .

$\mathrm{NO}_{3}{ }^{-}$content $\left(\mu \mathrm{g} \mathrm{g}^{-1}\right)=\mathrm{C} \times \mathrm{V} / \mathrm{M} \quad$ where,

$\mathrm{C}=$ concentration of $\mathrm{NO}_{3}{ }^{-}$in leaf sample $\left(\mu \mathrm{g} \mathrm{g}^{-1}\right)$

$\mathrm{V}=$ total volume of the sample solution $(100 \mathrm{ml})$

$\mathrm{M}=$ weight of the sample $(1.0 \mathrm{~g})$

The data obtained were converted to $\mathrm{mg} \mathrm{NO}_{3}^{-} \mathrm{g}^{-1}$ leaf D.W.

The same analytical method to determine $\mathrm{NO}_{2}{ }^{-}$content was followed except different reagents and conversion factor of 3.3 (LaMotte, 2000).

\section{Statistical analysis}

Appropriate analysis of variance on obtained results of the two experimental seasons was performed according to the design used (Snedecor and Cochran, 1980).Least significant difference test (LSD) at $p \leq 0.05$ level was utilized to verify the significant difference between treatments. 


\section{Results and Discussion}

\section{Growth measurements}

Fertilization of pumpkin plants with $2 / 3$ of the recommended $\mathrm{N}$ - mineral fertilizer and inoculation three times with a mixed bio-fertilizer significantly resulted in taller plant height, heavier canopy dry weight, more number of leaves and bigger area of leaves plant ${ }^{-1}$ than those inoculated one time and/or two times (Table 2).However, no significant difference in the aforementioned vegetative traits between fertilization with the recommended $\mathrm{N}$-mineral fertilizer dose (control) and the application $2 / 3$ recommended $\mathrm{N}$ - mineral fertilizer plus inoculation three times with a mixed bio-fertilizer. The noticeable increases of growth traits of pumpkin plants by the increase of applied bio-fertilizer dose may be related to the efficiency of non-symbiotic $\mathrm{N}_{2}$-fixing bacteria in the reduction of soil $\mathrm{pH}$ (Table 1) by secreting organic acids as acetic, propionic, fumaric and succinic (Singh and Kapoor, 1999) and consequently more solubility and availability of nutrients for plants are devoted. Also, Azotobacter and Azospirllum strains produced adequate amount of indole acetic acid, gibberellinslike substance and cytokinins which increased the surface area per unit root length and were responsible for root hair branching with an eventual increase in acquisition of nutrients from the soil (Martin et al., 1989 and Jagnow et al., 1991). Obtained results are in accordance with results of several investigators (Fayez et al., 1985, Abdel-Latif et al., 2001 and Gadallah \& El-Masry, 2006).In addition, Osman (2007), on potato and Howladar et al. (2013), on Brassica oleraceae, found that single inoculation of bio-N fertilizer or in combination with chemical fertilizers positively affected growth characters.

TABLE 2. Effect of mineral and bio-N fertilization on plant height, canopy dry weight, number and area of leaves plant ${ }^{-1}$ of pumpkin in 2012 and 2013.

\begin{tabular}{|c|c|c|c|c|}
\hline Treatments & $\begin{array}{c}\text { Plant } \\
\text { height } \\
(\mathrm{cm})\end{array}$ & $\begin{array}{c}\text { Canopy } \\
\text { DW } \\
\text { plant }^{-1}(\mathrm{~g})\end{array}$ & $\begin{array}{l}\text { No. leaves } \\
\text { plant }^{-1}\end{array}$ & $\begin{array}{c}\begin{array}{c}\text { Leaf area } \\
\text { plant }^{-1} \\
\left(\mathbf{d m}^{2}\right)\end{array} \\
\end{array}$ \\
\hline \multicolumn{5}{|c|}{2012 season } \\
\hline $\begin{array}{l}\text { Control } \quad(100 \% \\
\text { mineral-N) }\end{array}$ & $266 a^{*}$ & $164 \mathrm{a}$ & $58 \mathrm{a}$ & $191 \mathrm{a}$ \\
\hline Bio- $N_{1}+2 / 3$ mineral-N & $188 \mathrm{c}$ & $119 \mathrm{c}$ & $40 \mathrm{c}$ & $110 \mathrm{c}$ \\
\hline Bio- $\mathrm{N}_{2}+2 / 3$ mineral-N & $212 b$ & $128 b$ & $47 b$ & $152 b$ \\
\hline Bio- $\mathrm{N}_{3}+2 / 3$ mineral-N & $260 \mathrm{a}$ & $156 a$ & $56 a$ & $182 \mathrm{a}$ \\
\hline \multicolumn{5}{|c|}{2013 season } \\
\hline $\begin{array}{l}\text { Control } \quad(100 \% \\
\text { mineral-N) }\end{array}$ & $278 \mathrm{a}$ & $174 a$ & $62 a$ & $202 a$ \\
\hline Bio- $N_{1}+2 / 3$ mineral-N & $191 \mathrm{c}$ & $123 c$ & $41 c$ & $114 \mathrm{c}$ \\
\hline Bio- $\mathrm{N}_{2}+2 / 3$ mineral-N & $218 b$ & $133 b$ & $50 \mathrm{~b}$ & $158 b$ \\
\hline Bio- $\mathrm{N}_{3}+2 / 3$ mineral-N & $269 a$ & $165 a$ & $59 a$ & $192 \mathrm{a}$ \\
\hline
\end{tabular}

Control $=$ recommended dose of mineral-N fertilizer

Bio- $\mathrm{N}_{1}, \mathrm{~N}_{2}$ and $\mathrm{N}_{3}=$ inoculation with a mixed biofertilizer once, twice and thrice, orderly

*mean values within each column followed by a different lower-case letter(s) are significantly different using least significant difference test (LSD) at $P \leq 0.05$.

Egypt. J. Hort. Vol. 41, No.1 (2014) 


\section{Fruits yield and quality}

The statistical analysis proved that the influence of $\mathrm{N}$-mineral fertilization at the recommended dose(control) and fertilization with $2 / 3$ recommended $\mathrm{N}-$ mineral dose plus inoculation with the a mixed bio-fertilizer at three times on fruit length and diameter, average fruit weight and total fruits yield was at par(Table 4).Nevertheless, statistical lower mean values of the aforementioned fruits yield and quality parameters were obvious when fertilization was performed at $2 / 3$ recommended $\mathrm{N}$--mineral dose plus inoculation with a mixed bio-fertilize once and twice compared to the control treatment with few exceptions. These findings can be discussed on the basis that Bio-N acts as a nutrient reservoir through $\mathrm{N}_{2}$-fixation and $\mathrm{N}$ ions released slowly over the entire growth period. The slow and steady supply of $\mathrm{N}$ by bio-N, particularly at the three inoculants, satisfy the $\mathrm{N}$ requirements of plants at different growth stages and consequently leads to higher fruits yield. The favorable conditions of soil nutrients status as a result of addition $2 / 3$ mineral- $\mathrm{N}$ recommended dose and inoculation three times with a mixed bio-fertilizer (Table 1) aided in improvement of nutritional status of pumpkin plants (Table 3) which positively reflected on fruits yield. Our results are in agreement with those obtained by Osman (2007) and Howladar et al. (2013) who pointed out that total yield was highly correlated with the development of vegetative growth as well as dry matter accumulation.

TABLE 3. Effect of mineral and bio- $\mathrm{N}$ fertilization on fruit length and diameter, average fruit weight and total fruits yield of pumpkin in 2012 and 2013.

\begin{tabular}{|c|c|c|c|c|}
\hline Treatments & $\begin{array}{c}\text { Fruit } \\
\text { length } \\
\text { (cm) }\end{array}$ & $\begin{array}{c}\text { Fruit } \\
\text { diameter } \\
(\mathbf{c m})\end{array}$ & $\begin{array}{c}\text { Average } \\
\text { fruit weight } \\
(\mathrm{kg})\end{array}$ & $\begin{array}{c}\text { Fruit } \\
\text { yield } \\
\text { fed }^{-1} \text { (ton) }\end{array}$ \\
\hline \multicolumn{5}{|c|}{2012 season } \\
\hline${ }^{*}$ Control $(100 \%$ mineral-N) & $26.1 \mathrm{a}^{*}$ & $17.0 \mathrm{a}$ & $3.91 \mathrm{a}$ & $20.1 \mathrm{a}$ \\
\hline Bio- $\mathrm{N}_{1}+2 / 3$ mineral-N & $19.0 \mathrm{c}$ & $13.3 \mathrm{~b}$ & $2.89 \mathrm{c}$ & $14.6 \mathrm{c}$ \\
\hline Bio- $\mathrm{N}_{2}+2 / 3$ mineral-N & $22.2 b$ & $15.1 \mathrm{a}$ & $3.31 \mathrm{~b}$ & $17.6 \mathrm{~b}$ \\
\hline Bio- $\mathrm{N}_{3}+2 / 3$ mineral-N & $25.8 \mathrm{a}$ & $16.7 \mathrm{a}$ & $3.81 \mathrm{a}$ & $19.6 \mathrm{a}$ \\
\hline \multicolumn{5}{|c|}{2013 season } \\
\hline Control (100\% mineral-N) & $26.8 \mathrm{a}$ & $17.2 \mathrm{a}$ & $4.12 \mathrm{a}$ & $21.0 \mathrm{a}$ \\
\hline Bio- $\mathrm{N}_{1}+2 / 3$ mineral-N & $19.1 \mathrm{c}$ & $13.3 \mathrm{~b}$ & $3.00 \mathrm{c}$ & $15.0 \mathrm{c}$ \\
\hline Bio- $\mathrm{N}_{2}+2 / 3$ mineral-N & $22.7 b$ & $15.3 \mathrm{a}$ & $3.46 \mathrm{~b}$ & $18.1 \mathrm{~b}$ \\
\hline Bio- $\mathrm{N}_{3}+2 / 3$ mineral-N & $26.4 \mathrm{a}$ & $16.8 \mathrm{a}$ & $4.02 \mathrm{a}$ & $20.4 a$ \\
\hline
\end{tabular}

Control $=$ recommended dose of mineral-N fertilizer

Bio- $\mathrm{N}_{1}, \mathrm{~N}_{2}$ and $\mathrm{N}_{3}=$ inoculation with a mixed biofertilizer once, twice and thrice, orderly

"mean values within each column followed by a different lower-case letter(s) are significantly different using least significant difference test (LSD) at $P \leq 0.05$.

\section{Chemical constituents}

The influence of mineral and bio- $\mathrm{N}$ fertilization treatments on leaf $\mathrm{N}, \mathrm{P}$ and $\mathrm{K}$ contents was significant and the trend was identical in both years (Table 4). Similar contents of leaf N, P and K for pumpkin plants received. 
TABLE 4. Effect of mineral and bio- $N$ fertilization on nitrogen $(N)$, phosphorus $(P)$, potassium $(\mathrm{K})$, nitrate $\left(\mathrm{NO}_{3}{ }^{-}\right)$and nitrite $\left(\mathrm{NO}_{2}^{-}\right)$contents in leaf of pumpkin in 2012 and 2013.

\begin{tabular}{|c|c|c|c|c|c|}
\hline Treatments & $\begin{array}{c}\mathbf{N} \\
(\% \\
\text { DW })\end{array}$ & $\begin{array}{c}\mathbf{P} \\
(\% \\
\text { DW })\end{array}$ & $\begin{array}{c}\text { K } \\
(\% \\
D W)\end{array}$ & $\begin{array}{c}\mathrm{NO}_{3}^{-} \\
\left(\mathrm{mg} \mathrm{g}^{-1}\right. \\
\mathrm{DW})\end{array}$ & $\begin{array}{c}\mathrm{NO}_{2}^{-} \\
\left(\mathrm{mg} \mathrm{g}^{-1}\right. \\
\mathrm{DW})\end{array}$ \\
\hline \multicolumn{6}{|c|}{2012 season } \\
\hline${ }^{*}$ Control $(100 \%$ mineral-N) & $30.5 \mathrm{a}^{*}$ & $4.63 \mathrm{a}$ & $32.0 \mathrm{a}$ & $2.68 \mathrm{a}$ & $0.199 \mathrm{a}$ \\
\hline Bio- $\mathrm{N}_{1}+2 / 3$ mineral-N & $19.8 \mathrm{c}$ & $3.86 \mathrm{c}$ & $24.4 \mathrm{c}$ & $2.21 \mathrm{~b}$ & $0.124 \mathrm{~b}$ \\
\hline Bio- $\mathrm{N}_{2}+2 / 3$ mineral-N & $25.1 \mathrm{~b}$ & $4.31 b$ & $27.3 b$ & $1.67 \mathrm{c}$ & $0.097 \mathrm{c}$ \\
\hline Bio- $\mathrm{N}_{3}+2 / 3$ mineral-N & $29.8 \mathrm{a}$ & $4.58 \mathrm{a}$ & $31.5 \mathrm{a}$ & $0.96 \mathrm{~d}$ & $0.073 \mathrm{~d}$ \\
\hline \multicolumn{6}{|c|}{2013 season } \\
\hline Control (100\% mineral-N) & $28.8 \mathrm{a}$ & $4.90 \mathrm{a}$ & $33.9 \mathrm{a}$ & $2.53 a$ & $0.188 \mathrm{a}$ \\
\hline Bio- $\mathrm{N}_{1}+2 / 3$ mineral-N & $19.1 \mathrm{c}$ & $3.99 \mathrm{c}$ & $25.2 \mathrm{c}$ & $2.14 b$ & $0.120 \mathrm{~b}$ \\
\hline Bio- $\mathrm{N}_{2}+2 / 3$ mineral-N & $24.1 \mathrm{~b}$ & $4.49 \mathrm{~b}$ & $28.5 b$ & $1.60 \mathrm{c}$ & $0.093 \mathrm{c}$ \\
\hline Bio- $\mathrm{N}_{3}+2 / 3$ mineral-N & $28.3 \mathrm{a}$ & $4.85 \mathrm{a}$ & $33.2 \mathrm{a}$ & $0.91 \mathrm{~d}$ & $0.069 \mathrm{~d}$ \\
\hline
\end{tabular}

Control $=$ recommended dose of mineral-N fertilizer

Bio- $\mathrm{N}_{1}, \mathrm{~N}_{2}$ and $\mathrm{N}_{3}=$ inoculation with a mixed biofertilizer once, twice and thrice, orderly "mean values within each column followed by a different lower-case letter(s) are significantly different using least significant difference test (LSD) at $P \leq 0.05$.

Mineral-N at the recommended dose and those received mineral-Nat $2 / 3$ of the recommended dose + three inoculants of mixed bio-fertilizers. However, the two former fertilization treatments significantly surpassed the fertilization treatments of mineral-N at $2 / 3$ of the recommended dose +inoculation with bio- $\mathrm{N}$ fertilizer once or twice. The beneficial effects of non-symbiotic $\mathrm{N}_{2^{-}}$fixing bacteria of genera Azotobacter chroococcum and Azospirillium brasilense in production of Phytohormones, better root proliferation, improving the availability and acquisition of nutrients had been documented (Kundu \& Gaur, 1980 and Vessey, 2003). Similar results on marigold and tomato plants were reported by Barakat \& Said (1998) and Balasubramanian (1989), orderly.

The combined treatments of mineral-N fertilization at $2 / 3$ of the recommended level + inoculation with a mixed bio- $\mathrm{N}$ fertilizer; once, twice or thrice significantly had lower mean contents of $\mathrm{NO}_{3}^{-}$and $\mathrm{NO}_{2}^{-}$than the control treatment. The least significant mean value of $\mathrm{NO}_{3}^{-}$and $\mathrm{NO}_{2}^{-}$contents was recorded when pumpkin plants were fertilized with $2 / 3$ of the recommended mineral-N fertilizer and inoculated three times with the mixed bio-fertilizer. These results can be discussed on the basis that application of mineral-N at the recommended dose (control) possibly led to continuous and accumulated supply of $\mathrm{NO}_{3}{ }^{-}$and $\mathrm{NO}_{2}{ }^{-}$(Mahmoud et al., 2009 and Howladar et al., 2013). In contrast, when mineral-N was reduced and inoculation with bio-fertilizer was performed, the release of $\mathrm{NO}_{3}{ }^{-}$and $\mathrm{NO}_{2}{ }^{-}$was comparatively fewer and slow due to increasing organic matter which regulates the release and transformation of $\mathrm{N}$-fertilizer to $\mathrm{NO}_{3}{ }^{-}$and $\mathrm{NO}_{2}{ }^{-}$.

Egypt. J. Hort. Vol. 41, No.1 (2014) 


\section{Conclusion}

Bio-N fertilizers reduced the amount of synthetic chemical-N fertilizer needed and reduced the negative effects of chemical-N fertilizer on the environment including nitrate and nitrite accumulation in plants. Moreover, increased soil organic matter content and the availability of nutrients to plant roots, thus increased plant growth and yields.

\section{References}

A.O.A.C. (1995) Official Methods of Analysis.15 ${ }^{\text {th }}$ ed., Washington, D.C., USA.

Abdel-Latif, M.R., El-Bana, A.A. and Galal, A.A. (2001) Effect of biofertilizers microbein and phosphorine on bacterial pod blight of guar and black cumin damping off root rot and with diseases. Proc. of the Fifth Arabian Horticulture Conference, Ismailia, Egypt, March 24-28, 133 - 140.

Ashour, S.A., Abdel-Fattah, A.E. and Tawfik, A.A. (1997) Effect of nitrobin (biofertilizer) and different levels of nitrogen on growth and yield of potato (Solanum tuberosum, L.) J. Agric. Sci. Mansoura Univ. 22, 3979 - 3986.

Balasubramanian, J. (1989) Studies on the combined effect of Azospirillium VA mycorrhizal and inorganic fertilizers on growth performance of French marigold (Tegetes putula L.). SIH, 37, 311.

Barakat, M.A.S. and Said, M.G. (1998) Effect of different bioferetilizer types and nitrogen fertilizer levels on tomato plants. Alex. J. Agric. Res., 43(1), 149 - 160.

Bhatia, A., Pathak, H. and Joshi, H.C. (2001) Use of sewage as a source of plant nutrient: potentials and problems. Fert. News, 46, 55-58.

Cocking, E.C. (2000) Helping plants get more nitrogen from air. European Review, 8, 193-200.

Dobereiner, J., Marril, I.E. and Niery, M. (1976) Ecological distribution of Spirillum lipoferum, Beijerinek. Can. J. Microbiol., 22, 1464-1473.

Fayez, M., Eman, N.F. and Makbol, H.E. (1985) The possible use of nitrogen fixing Azospirillum as biofertilizer for wheat plants. Egypt. J. Microbiol., 20, 199-206.

Gadallah, F.M. and El-Masry, T.A. (2006) Onion growth and yield as affected by biofertilization. Annals Agric. Sci. Moshtohor, 44, 987-1005.

Hanafy, A.H., Kheir, N.F. and Talaat, N.B. (1997) Physiological studies on reducing the accumulation of nitrate in jew's mallow (Corchorus olitorius) and radish (Raphanus sativus L.). Bull. Fac. Agric. Cairo Univ., 48, 25-64.

Hartman, A. (1988) Ecophysiological aspects of growth and nitrogen fixation in Azospirillium species. Plant Soil, 110, 225-238. 
Hegazi, N.A. and Niemela, S. (1976) A note on the estimation of Azotobacter density by membrane filter technique. J. Appl. Bacteriol., 41, 311.

Howladar, S.M., Rady, M.M. and Osman, A.Sh. (2013) Effect of bio-nitrogen as a partial alternative to mineral-nitrogen fertiliser on growth, nitrate and nitrite contents, and yeld quality in Brassica oleracea L. World Academy of Science, Engineering and Technology, International Science Index 79, International J. of Agricultural Sci. and Engineering, 7, 200-205. http://waset.org/Publications/effect-of-bio-nitrogen-as-apartial-alternative-to-ineral-nitrogen-fertiliser-on-growth- nitrate-and-nitrite-contentsand-yield-quality-in-brassica-oleracea-1./16334.

Ibrahim, A.N. and Abd El-Aziz, I.M. (1977) Solubilization of rock phosphate by streptomyces. Agr. Talajton, 26, 424-434.

Jackson, M.L. (1967) Soil Chemical Analysis, New Jersey Prentice-Hall, Inc.

Jagnow, G., Hoflich, G. and Hoffmann, K.H. (1991) Inoculation of non-symbiotic rhizosphere bacteria: possibility of increasing and stabilizing yields. Angew Botanik, 65, $97-126$.

Kundu, B.S. and Gaur, A.C. (1980) Effect of phosphor bacteria on the yield and phosphate Uptake of potato crop. Current Sci., 49, 159-160.

La Motte, (2000) Smart spectro water and waste water procedure analysis manual. La Motte Inc., Washington, DC, USA . 68-180.

Mahmoud, E., Abd El-Kader, N., Robin, P., Akkal-Corfini, N. and Abd El-Rahman, L. (2009) Effects of different organic and inorganic fertilizers on cucumber yield and some soil properties. World J. Agric. Sci., 5, 408-414.

Martin, P., Glatzle, A., Klob, W., Omay, H. and Schmidt, W. (1989) Nitrogen fixing bacteria in the rhizosphere: quantification and hormonal effects on root development. Z. Pflanzerahr. Bodenk, 152, 237 - 245.

Osman, A.Sh. (2007) Effect of partial substitution of mineral-N by biofertilization on growth, yield and yield components of potato. The Third Conf. of Sustain. Agric. Develop. Fac. of Agric., Fayoum Univ., 12-14 Nov., 381 - 396.

Page, A.I., Miller, R.H. and Keeney, D.R. (1982) Methods of Soil Analysis. Part 2: Chemical and Microbiological Properties. $2^{\text {nd }}$ ed., Amer. Soc. of Agron., Madison, Wisconsin, U.S.A.

Palm, C.A., Gachengo, C.N., Delve, R.J., Cadisch, G. and Giller, K.E. (2001) Organic inputs for soil fertility management in tropical agro ecosystems: application of an organic resource database. Agric. Ecosyst. Environ., 83, 27-42.

Radojevic, M. and Bashkin, N.V. (1999) Practical Environmental Analysis, Royal Society of Chemistry and Thomas Graham House, Cambridge, UK . 180-430.

Singh, S. and Kapoor, K.K. (1999) Inoculation with phosphate- solubilizing microorganisms and visicular-arbuscular mycorrhizal fungus improves dry matter yield and nutrient uptake by wheat grown in sandy soil. Biol. Ferti. Soils, 28, 139-144.

Egypt. J. Hort. Vol. 41, No.1 (2014) 
Singh, N.P., Sachan, R.S., Pandey, P.C. and Bisht, P.S. (1999) Effect of a decade long fertilizer and manure application on soil fertility and productivity of rice-wheat system in Molisols. J. The Indian Soc. Soil Sci., 47, 72-80.

Snedecor, G.W. and Cochran, W.G. (1980) Statistical Methods. $7^{\text {th }}$ ed., Oxford and J. B. H. Publ. Com.

Vessey, K.J. (2003) Plant growth promoting rhizobacteria as biofertilizer. Plant and Soil, $255,571-586$.

Wilde, S.A., Corey, R.B., Lyer, J.G. and Voigt, G.K. (1985) Soil and Plant Analysis for Tree Culture, $3^{\text {rd }}$ ed. Oxford and IBM Publishers. New Delhi. India. pp. 93-106.
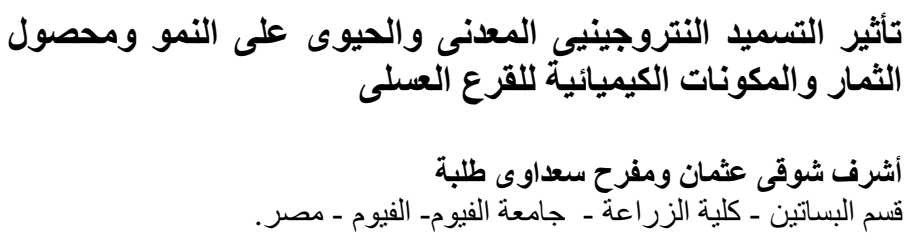

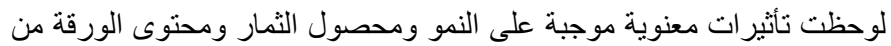

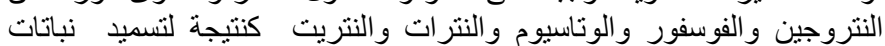

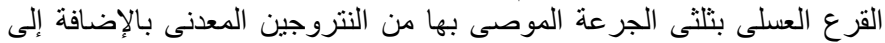
ثلاثة تلقيحات من السماد الحيوى المختلط المحتى لثرى على بكتريا مقارنة بتسميد النباتات chroococcum and Azospirillium brasilense بثلثى الجرعة الموصى بها من النتروجين المعدنى والتلقيح بالسماد الحيوى التئي

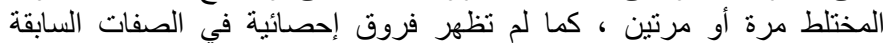

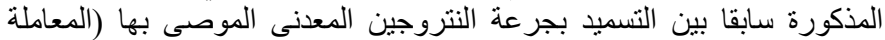

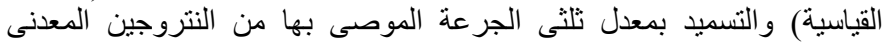

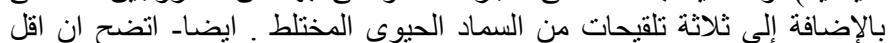

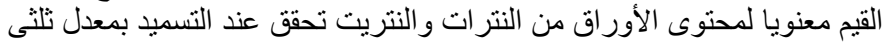

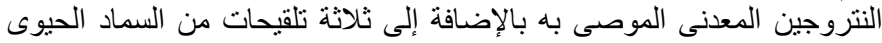

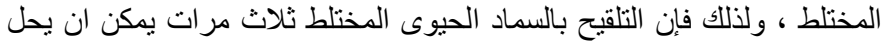

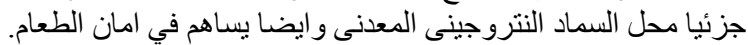

